DOI: https://doi.org/10.15407/techned2022.01.075

\title{
CORRECTION OF ERRORS OF THE MEASURING CHANNEL AVERAGE ACTIVE POWER
}

\author{
D.P. Ornatskyi ${ }^{1 *}$, S.V. Yehorov ${ }^{* * *}$, V.V. Dovhan ${ }^{2 * * *}$ \\ ${ }^{1}$ National Aviation University, \\ Husar Lubomyr ave., 1, Kyiv, 03058, Ukraine, \\ e-mail: ornatskiyd@ukr.net, sehorov@gmail.com \\ ${ }^{2}$ SE "UKRMETRTESTSTANDART", \\ Metrologichna str., 4, Kyiv, 03143, Ukraine, \\ e-mail: dovgan csm@ukr.net
}

In the article is offered the structural scheme of error correction of the precision measuring channel of average active power for researches in laboratory conditions and exclusively within the limits of changes of the basic frequency of a network. A feature of the scheme is the use of calibration of functional transducers with piecewise linear approximation. The input voltages of these converters are a triangular voltage, which is formed at the output of the integrator by integrating rectangular bipolar meanders, which are formed from the output signals of the frequency divider phase shifter synchronized with the network by a device based on the original precision amplitude-pulse system of phase frequency tuning. Compensatory small-sized low-voltage transformers using measuring amplifiers with differentially split inputs are used as primary converters, which increases the linearity of the characteristic in a wide dynamic range, due to which additive-multiplicative correction of errors of the whole measuring path by two points is realized. The article presents the results of computer modeling of the main functional components of the measuring channel, which confirm its precision and high metrological characteristics. References 10, figures 2.

Keywords: automatic error correction, active power, measuring channel, synchronization system, frequency components of errors, phase-locked loop.

Introduction. The main feature of measuring transducers of average active power is the need to use filtering of input signals while reducing the influence of higher harmonics [1]. In this case, as a result of nonidentity of the frequency characteristics of the filters, errors occur, both phase, which are associated with non-identity of phase-frequency characteristics of filters and amplitude, which are associated with nonuniformity of amplitude-frequency characteristics of filters. In addition, a significant contribution to the frequency errors will be made by the input transformers, which are usually used as primary converters of input voltages and currents. As a rule, the frequency errors of the converters of average electric power are corrected at fixed frequencies and do not cover the input transformers. A similar problem was considered in subsequent publications [2-4].

Research tasks. The purpose of the article is to create an experimental sample of a precision active power meter for research in the laboratory and only within the limits of changes in the fundamental frequency of the network $(50 \pm 5) \mathrm{Hz}$.

The main material. The block diagram of the measuring channel for single-phase connection is presented in Fig. 1, which adopted the following abbreviations: FDPS is the frequency divider phase $\mathrm{P} / 4$ shifter; FC1, FC2 is the functional converter, which is made according to the known scheme of functional converters with piecewise linear approximation based on the operational amplifier, 12 segments will suffice to obtain the average directional value of a sinusoidal signal with an error of less than $0.1 \%$ [5]; TSD is the two-and-a-half-period synchronous detector; BIS is the block of input signals; FM- frequency multiplier; TT is the T-trigger; IIC integrating iterative converter; MX1, MX3 is the digital multiplexers; MX2, MX4 are

(C) Ornatskyi D.P., Yehorov S.V., Dovhan V.V., 2022

ORCID ID: * https://orcid.org/0000-0002-5776-5325; ** https://orcid.org/0000-0001-6976-2394 ;

*** https://orcid.org/0000-0003-1614-2567 
the analog multiplexers;CRT1, CRT2 is the converter of a rectangular signal shape into a triangular one; $\delta$ - $\Sigma$ is the delta-sigma modulator; $\mu \mathrm{c}$ is the microcontroller (8051); $U_{0}$ is the source of constant reference voltage; BUS is the $\mathrm{I} / \mathrm{O}$ bus.

A feature of the scheme is the use of calibration of functional transducers with piecewise-linear approximation. The input voltages of these converters are a triangular voltage, which is formed at the output of the integrator by integrating rectangular bipolar meanders, which are formed from the output signals of the frequency divider phase shifter (FDPS) synchronized with the network using a device that increases the frequency by four times the frequency multiplier (FM). Made on the basis of the original precision amplitude-pulse system of phase-locked loop (PLL) [6]. Compensatory small-sized low-voltage transformers with the use of measuring amplifiers with differentially split inputs are used as primary converters. This gives an increase in the linearity of the characteristic in a wide dynamic range due to which the additivemultiplicative correction of errors of the entire measuring path at two points is realized [7].

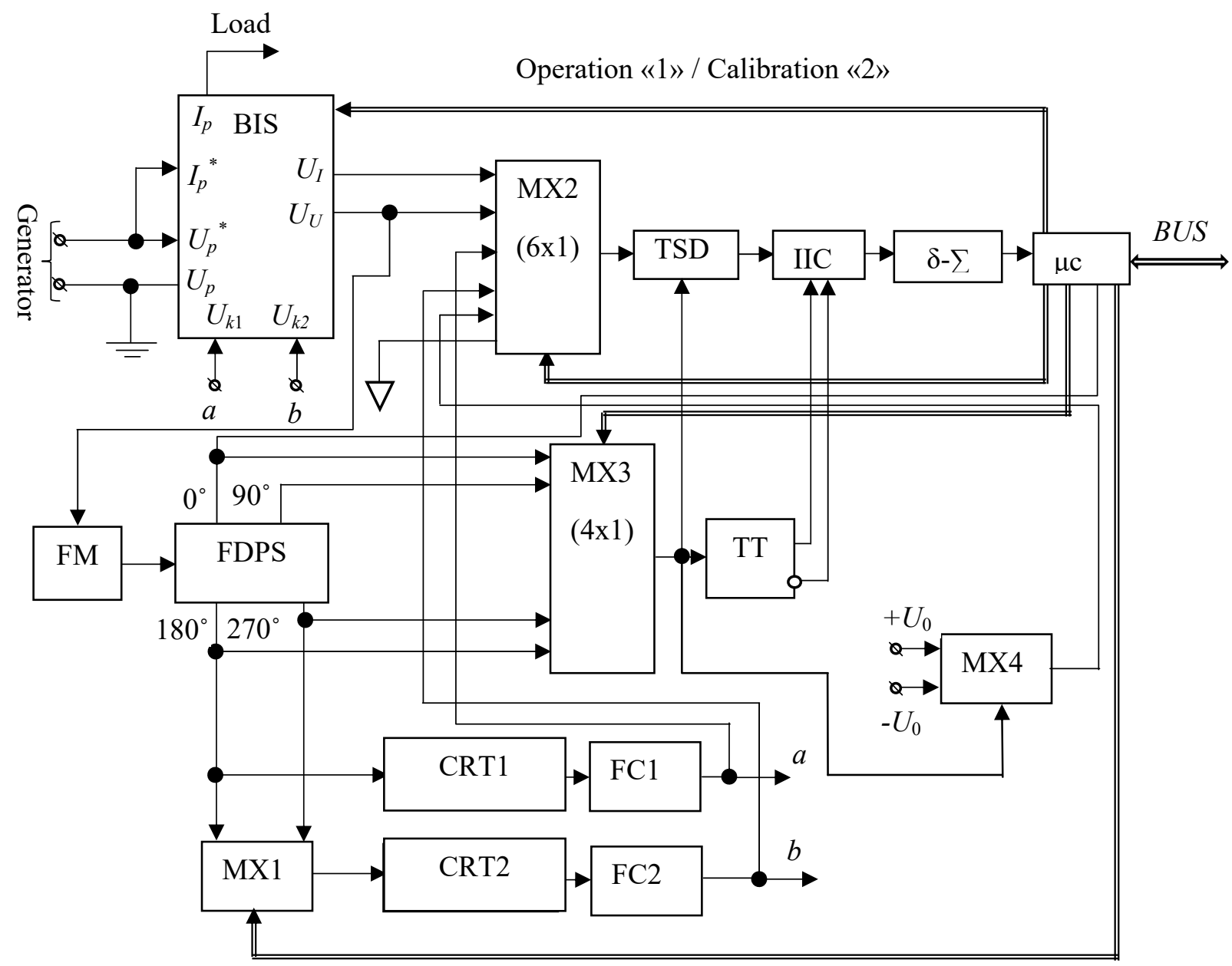

Fig. 1

The scheme works as follows. The input signals of the phase voltage $U_{p}$ and the phase current $I_{p}$, or their linear analogues, depending on the method of accounting for three-phase power (three-element or twoelement circuit), are converted in the switching unit and conversion of input signals into proportional voltages $U_{U}$ and $U_{I}$, respectively. Resistor dividers together with low-voltage voltage transformers VT1 and VT2 on ferrite cores are used as primary converters of primary voltages and currents (Fig. 2). To improve the linearity of the conversion function of these transformers, the primary and secondary windings are wound on the technology of "countercurrent" [8], which provides a non-linearity error of less than $0.01 \%$ in the dynamic range over $20 \mathrm{~dB}$ [9], exceeding the required multiplicity of 1:5. To build VT1 and VT2, a double ring core K32x16x12 made of soft non-thermostable manganese-zinc ferrites of general use type 3000NM is 
used. The windings contain 140 turns of SEW2 wire with a diameter of $0.3 \mathrm{~mm}$ and have the following parameters: inductance $\approx 0.2 \mathrm{H}$, resistance $\mathrm{Rs} \approx 2.4 \mathrm{Ohm}$, which determines the low-frequency pole, which is approximately equal to $2 \mathrm{~Hz}$.

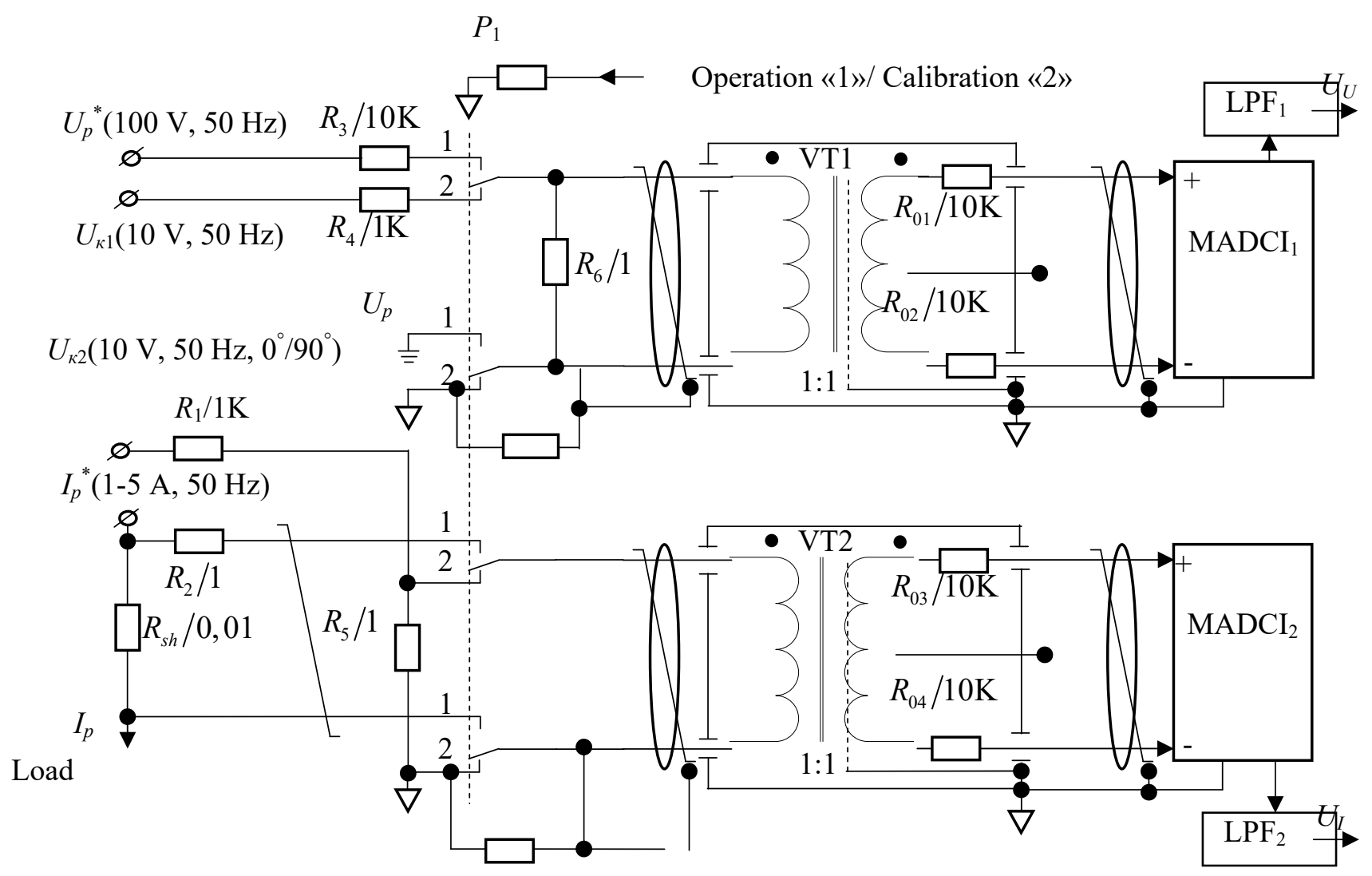

Fig. 2

This provides, together with the measuring amplifier with differential current inputs (MADCI), the phase shift deviation on each channel $\approx 0.5^{\circ}$ in the frequency band $(50 \pm 2.5) \mathrm{Hz}$ and the amplitude error of the order of $0.02 \%$. In the filters LPF1, LPF2 to minimize the phase errors introduced by them, cower approximation (Elliptical filters) [10] with the location of the flat part of the phase frequency response in the range $(50 \pm 2.5) \mathrm{Hz}$, with frequency deviation in this range caused a phase shift of about $0.2^{\circ}$. In addition, the sensitivity of this characteristic to changes in RC elements did not exceed $0.3^{\circ}$ by $1 \%$. This means that when using precision resistors of class 0.05 and capacitors of class 0.25 , the error of the phase shift of the filters will not exceed $0.4^{\circ}$ per channel. Thus, the final initial phase shift between the signals $U_{U}, U_{I}$ (Fig. 2) with no identity of the components of $10 \%$ will not exceed $0.1^{\circ}$ in the frequency range $(50 \pm 2.5) \mathrm{Hz}$. This will allow calibration of the measuring channel of the average active power at two points.

To reduce the phase-frequency matching errors of transformers VT1, VT2, the latter are made identical and the output resistance of resistive dividers and shunts has the same value, about $1 \mathrm{Ohm}$ in all modes of operation and calibration. In the "operation" mode, the mechanically interconnected moving contacts of the relay P1 are in position "1" while the mains phase voltage $U_{p}(100 \mathrm{~V}, 50 \mathrm{~Hz})$ through the first divider formed by precision resistors R3, R6 falls on the primary winding of the transformer VT1. The transfer factor of this divider $k_{g l}$ is equal to:

$$
k_{g 1}=\frac{R_{6}}{R_{3}+R_{6}}=10^{-4} .
$$

The actual value of this factor is stored in the memory of the microcontroller $\mu \mathrm{c}$. The primary winding of the transformer VT2, in this case through the resistor $R_{2}$ receives a voltage from the shunt $R_{s h}$, the 
value of which is stored in the memory of the microcontroller $\mu \mathrm{c}$. To increase noise immunity and linearity, signals from the secondary windings of transformers VT1 and VT2 through the same sample resistors $R_{01}-R_{04}$ fall on the inputs of measuring amplifiers with differential current inputs (MADCI1 and MADCI2) whose output signals are filtered. LPF1, LPF2 at the outputs of which the output signals $U_{U}$ and $U_{I}$ are formed in proportion to the phase voltage and current, respectively:

$$
\begin{aligned}
& U_{U}=U_{p} k_{g 1} k_{V T 1}^{*} k_{M A D C I 1} k_{L P F 1} ; \\
& U_{I}=I_{p} R_{s h} k_{V T 2}^{*} k_{M A D C I 2} k_{L P F 2},
\end{aligned}
$$

where $U_{p}$ is the phase voltage; $I_{p}$ is the phase current; $k_{V T 1}^{*}$ and $k_{V T 2}^{*}$ are the values of the transfer coefficient of transformers VT1 and VT2, taking into account the errors of coordination; $k_{M A D C I_{1}}$ and $k_{M A D C I_{2}}$ are the values of the transmission factor of the measuring amplifiers MADCI1 and MADCI2; $k_{L P F_{1}}$ and $k_{L P F_{2}}$ are the values of the transfer factor of the filters LPF1 and LPF2, respectively; $R_{s h}$ is the shunt resistance.

With the help of MX2, MX3, IIC, ADC and $\mu \mathrm{c}$, the quadrature components of the BIS output voltages are determined sequentially in time:

$$
\begin{aligned}
& U_{U}\left(U_{p}\right)=(a+j b) ; \\
& U_{I}\left(I_{p}\right)=(c+j d),
\end{aligned}
$$

where

$$
\begin{array}{ll}
a=\frac{\left\{N\left(U_{U}\left(U_{p}\right) \mid 0^{\circ}\right\}-N(0)\right.}{N\left(U_{0}\right)-N(0)} U_{0}^{*}, & b=\frac{\left\{N\left(U_{U}\left(U_{p}\right) \mid 90^{\circ}\right\}-N(0)\right.}{N\left(U_{0}\right)-N(0)} U_{0}^{*}, \\
c=\frac{\left\{N\left(U_{I}\left(I_{p}\right) \mid 0^{\circ}\right\}-N(0)\right.}{N\left(U_{0}\right)-N(0)} U_{0}^{*}, & d=\frac{\left\{N\left(U_{I}\left(I_{p}\right) \mid 90^{\circ}\right\}-N(0)\right.}{N\left(U_{0}\right)-N(0)} U_{0}^{*},
\end{array}
$$

where $\left\{N\left(U_{U}\left(U_{P}\right) \mid 0^{\circ}\right\}\right.$ is the result of analog-to-digital conversion of the output voltage of the IIC at the phase shift angle of the control signal TSD is $0^{\circ} ;\left\{N\left(U_{U}\left(U_{P}\right) \mid 90^{\circ}\right\}\right.$ is the result of analog-to-digital conversion of the output voltage of the IIC at the phase shift angle of the control signal DSD is $90^{\circ}$; $\left\{N\left(U_{I}\left(I_{P}\right) \mid 0^{\circ}\right\}\right.$ is the result of analog-to-digital conversion of the output voltage of the IIC at the phase shift angle of the control signal TSD is $0^{\circ} ;\left\{N\left(U_{I}\left(U_{I}\right) \mid 90^{\circ}\right\}\right.$ is the result of analog-to-digital conversion of the output voltage of the IIC at the phase shift angle of the control signal DSD is $90^{\circ} ; N\left(U_{0}\right)$ is the result of analog-to-digital conversion of the output voltage IIC of the source of the reference signal $\pm U_{0} ; N(0)$ is the result of analog-to-digital conversion of the zero input voltage of the TSD, in the last two cases the phase of the control signal of the TSD is preserved.

In the "calibration" mode (Fig. 2) the primary winding of transformers VT1 and VT2 receives voltage from the inputs of BIS $U_{\kappa 1}$ and $U_{k 2}$, respectively. Scaling of these stresses is performed using two identical voltage dividers $k_{g 2}$ and $k_{g 3}$, respectively. The values of the transfer coefficients of these dividers will be equal and presented in the form:

$$
\begin{aligned}
& k_{g 2}=\frac{R_{6}}{R_{4}+R_{6}}=10^{-3}, \\
& k_{g 3}=\frac{R_{5}}{R_{1}+R_{5}}=10^{-3} .
\end{aligned}
$$

The value of these coefficients is stored in the memory of the microcontroller $\mu \mathrm{c}$. Resistors $R_{1}, R_{3}$ $R_{6}$ are precision.

In the "calibration" mode, which consists of three stages, in the first stage the digital multiplexer MX1 ensures the coherence of the calibration signals BIS $U_{k 1}$ and $U_{k 2}$, for this control signals CRT1 and 
CRT2 are selected the same and have a phase of $180^{\circ}$. The voltage at the outputs of the BIS will have the following values:

$$
\begin{gathered}
U_{U}\left(U_{k 1}\right)=U_{k 1} k_{g 2} k_{V T 1}^{*} k_{M A D C I 1} k_{L P F 1}, \\
U_{I}\left(U_{k 2}\right)=U_{k 2} k_{g 3} k_{V T 2}^{*} k_{M A D C I 2} k_{L P F 2}, \\
U_{U}\left(U_{k 1}\right)=(e+j f), \\
U_{I}\left(U_{k 2}\right)=(m+j n),
\end{gathered}
$$

where

$$
\begin{array}{lr}
e=\frac{\left\{N\left(U_{U}\left(U_{k 1}\right) \mid 0^{\circ}\right\}-N(0)\right.}{N\left(U_{0}\right)-N(0)} U_{0}^{*}, & f=\frac{\left\{N\left(U_{U}\left(U_{k 1}\right) \mid 90^{\circ}\right\}-N(0)\right.}{N\left(U_{0}\right)-N(0)} U_{0}^{*}, \\
m=\frac{\left\{N\left(U_{I}\left(U_{k 2}\right) \mid 0^{\circ}\right\}-N(0)\right.}{N\left(U_{0}\right)-N(0)} U_{0}^{*}, & n=\frac{\left\{N\left(U_{I}\left(U_{k 2}\right) \mid 90^{\circ}\right\}-N(0)\right.}{N\left(U_{0}\right)-N(0)} U_{0}^{*},
\end{array}
$$

where $\left\{N\left(U_{U}\left(U_{k l}\right) \mid 0^{\circ}\right\}\right.$ is the result of analog-to-digital conversion of the output voltage of the IIC at the phase shift angle of the control signal TSD is $0^{\circ} ;\left\{N\left(U_{U}\left(U_{k l}\right) \mid 90^{\circ}\right\}\right.$ is the result of analog-to-digital conversion of the output voltage of the IIC at the phase shift angle of the control signal TSD is $90^{\circ}$; $\left\{N\left(U_{I}\left(U_{k 2}\right) \mid 0^{\circ}\right\}\right.$ is the result of analog-to-digital conversion of the output voltage of the IIC at the phase shift angle of the control signal TSD is $0^{\circ}$; $\left\{N\left(U_{I}\left(U_{k 2}\right) \mid 90^{\circ}\right\}\right.$ is the result of analog-to-digital conversion of the output voltage of the IIC at the phase shift angle of the control signal TSD is $90^{\circ}$.

In the mode of "calibration" in the second stage by means of the digital multiplexer MX1 which the quadrature of calibration signals is provided. This determines the quadrature components of the output signals of the BIS, which have the following values:

$$
\begin{aligned}
& U_{U}\left(U_{k 1}\right)=(g+j h) ; \\
& U_{I}\left(I_{k 2}\right)=(p+j q),
\end{aligned}
$$

where

$$
\begin{array}{ll}
g=\frac{\left\{N\left(U_{U}\left(U_{k 1}\right) \mid 0^{\circ}\right\}-N(0)\right.}{N\left(U_{0}\right)-N(0)} U_{0}^{*}, & h=\frac{\left\{N\left(U_{U}\left(U_{k 1}\right) \mid 90^{\circ}\right\}-N(0)\right.}{N\left(U_{0}\right)-N(0)} U_{0}^{*}, \\
p=\frac{\left\{N\left(U_{I}\left(U_{k 2}\right) \mid 0^{\circ}\right\}-N(0)\right.}{N\left(U_{0}\right)-N(0)} U_{0}^{*}, & q=\frac{\left\{N\left(U_{I}\left(U_{k 2}\right) \mid 90^{\circ}\right\}-N(0)\right.}{N\left(U_{0}\right)-N(0)} U_{0}^{*},
\end{array}
$$

where $\left\{N\left(U_{U}\left(U_{k l}\right) \mid 0^{\circ}\right\}\right.$ is the result of analog-to-digital conversion of the output voltage of the IIC at the phase shift angle of the control signal TSD - $0^{\circ} ;\left\{N\left(U_{U}\left(U_{k l}\right) \mid 90^{\circ}\right\}\right.$ is the result of analog-to-digital conversion of the output voltage of the IIC at the phase shift angle of the control signal TSD - $90^{\circ}$; $\left\{N\left(U_{I}\left(U_{k 2}\right) \mid 0^{\circ}\right\}\right.$ is the result of analog-to-digital conversion of the output voltage of the IIC at the phase shift angle of the control signal TSD $-0^{\circ} ;\left\{N\left(U_{I}\left(U_{k 2}\right) \mid 90^{\circ}\right\}\right.$ is the result of analog-to-digital conversion of the output voltage of the IIC at the phase shift angle of the control signal TSD - $90^{\circ}$.

In the "calibration" mode at the third stage the quadrature components of the output voltages of the functional converters $\mathrm{FC} 1$ and $\mathrm{FC} 2$ are determined:

$$
\begin{aligned}
& U_{F C 1}=(k+j l) ; \\
& U_{F C 2}=(r+j s),
\end{aligned}
$$

where

$$
k=\frac{\left\{N\left(U_{F C 1}\right) \mid 0^{\circ}\right\}-N(0)}{N\left(U_{0}\right)-N(0)} U_{0}^{*}, \quad l=\frac{\left\{N\left(U_{F C 1}\right) \mid 90^{\circ}\right\}-N(0)}{N\left(U_{0}\right)-N(0)} U_{0}^{*}
$$




$$
r=\frac{\left\{N\left(U_{F C 2}\right) \mid 0^{\circ}\right\}-N(0)}{N\left(U_{0}\right)-N(0)} U_{0}^{*}, \quad s=\frac{\left\{N\left(U_{F C 2}\right) \mid 90^{\circ}\right\}-N(0)}{N\left(U_{0}\right)-N(0)} U_{0}^{*}
$$

where $\left\{N\left(U_{F C l}\right) \mid 0^{\circ}\right\}$ is the result of analog-to-digital conversion of the output voltage of the IIC at the phase shift angle of the control signal TSD - $0^{\circ} ;\left\{N\left(U_{F C l}\right) \mid 90^{\circ}\right\}$ is the result of analog-to-digital conversion of the output voltage of the IIC at the phase shift angle of the control signal TSD - $90^{\circ} ;\left\{N\left(U_{F C 2}\right) \mid 0^{\circ}\right\}$ is the result of analog-to-digital conversion of the output voltage of the IIC at the phase shift angle of the control signal TSD - $0^{\circ} ;\left\{N\left(U_{F C 2}\right) \mid 90^{\circ}\right\}$ is the result of analog-to-digital conversion of the output voltage of the IIC at the phase shift angle of the control signal TSD $-90^{\circ}$.

The obtained data allow to obtain an adjusted result:

$$
P_{c o r r}=A \sqrt{\frac{(a c-b d)^{2}+(b c+d a)^{2}}{(m e-n f)^{2}+(n e+m f)^{2}}\left[(r k-s l)^{2}-(k s+r l)^{2}\right]} \cos \left[\operatorname{arctg}\left(\frac{b c+a d}{a c-b d}\right)-\Delta \varphi\right]
$$

where $\Delta \varphi=\operatorname{arctg}\left(\frac{h p+g q}{g p-h q}\right), A=\frac{k_{g 2}^{*} \cdot k_{g 3}^{*}}{R_{s h}^{*} \cdot k_{g 1}^{*}}, k_{g 1}^{*}, k_{g 2}^{*}, k_{g 3}^{*}$ are the transfer coefficients of the respective divisors, which are stored in computer memory; $R_{s h}^{*}$ is the resistance of the shunt, which is stored in computer memory.

Conclusions. The proposed scheme allows you to adjust not only the error of change of the modulus of the transmission factor, but also the phase error in the operating frequency range. Due to this, it is possible to use high-quality filters, which will reduce the influence of higher harmonics, the level of which today is quite high and exceeds $10 \%$.

The result obtained by expression (10) will be free from systematic additive and multiplicative errors of all components of the measuring channel including the frequency component of the error, and the accuracy class of the measuring channel will be determined by the accuracy class of sample voltage dividers $k_{g 1}, k_{g 2}, k_{g 3}$ shunt resistance $R_{s h}$ and reference voltage source $U_{0}$.

1. State Standard of Ukraine EN 60688:2014 (EN 60688:2013, IDT; IEC 60688:2012, IDT) Electrical measuring transducers for converting A.C. and D.C. electrical quantities to analogue or digital signals. Kyiv, UkrNDNTs, 2014, 40 p. (Ukr)

2. Tankevich E.M., Varsky G.M., Yakovleva I.V. Influence of components of the measuring channel on errors of measurement of voltage vectors. Tekhichna Elektrodynamika. 2011. No 6. Pp. 41-47. (Ukr)

3. Stogniy B.S., Sopel M.F., Varsky G.M., Yakovleva I.V. Three-phase measuring channels of voltage and current vectors, their influence on measurement accuracy. Tekhichna Elektrodynamika. 2014. No 1. Pp. 81-87. (Ukr)

4. Varsky G.M., Sopel M.F., Tankevich E.M., Yakovleva I.V. Correction of errors of measuring current channels in means of monitoring of a normal mode of power system. Tekhichna Elektrodynamika. 2014. No 1. Pp. 7173. (Ukr)

5. SchifferV., Evans W.A. Approximations in Senewave Generation and Synthesis. The radioelectron. engr. 1978. Vol. 48. No 3. Pp. 113-121. (Eng)

6. Ornatsky D.P., Ornatsky E.P. Pulse frequency multiplier. Author's certificate USSR No 470920, 1975. (Rus)

7. Pulyaev V.I., Usachev Yu.V. Digital registration of emergency events in power systems. Moskva: NTF Energoprogress, 1999. 80 p. (Rus)

8 Surdu M.M., Monastyrsky Z.Y. Variational methods for improving the accuracy of immittance meters. Kyiv: Institute of Electrodynamics of the National Academy of Sciences of Ukraine, 2015. Pp. 373-385. (Ukr)

9. Ornatsky D.P., Kotlyar V.S., Kvashena O.P., Olinishin O.A. Digital registrator of emergency processes for industrial networks. Avtomatyzatsiia vyrobnychih protsesiv. 2004. No 1 (18). Pp. 156-158. (Rus)

10. Temesha G., Mitra S. Modern theory of filters and their design. Moskva: Publishing MIR, 1977. 467 p. (Rus) 


\title{
КОРЕКЦІЯ ПОХИБОК ВИМІРЮВАЛЬНОГО КАНАЛУ СЕРЕДНЬОЇ АКТИВНОЇ ПОТУЖНОСТІ
}

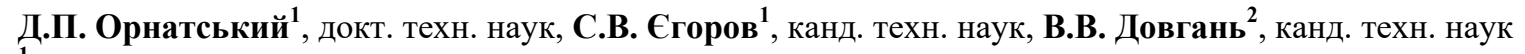 \\ ${ }^{1}$ Національний Авіаційний Університет, \\ пр. Гузара Любомира, 1, Київ, 03058, Україна, \\ e-mail: ornatskiyd@ukr.net, sehorov@gmail.com \\ ${ }^{2}$ ДП «УКРМЕТРТЕСТСТАНДАРТ \\ вул. Метрологічна, 4, Київ, 03143, Україна, \\ e-mail: $\quad$ dovgan csmaukr.net
}

У статті запропоновано структурну схему корекції похибок прецизійного вимірювального каналу середньої активної потужності для досліджень в лабораторних умовах та виключно в межах змін основної частоти мережі. Особливістю схеми є використання під час калібрування функціональних перетворювачів 3 кусковолінійною апроксимацією. При цзьому вхідними напругами цих перетворювачів є трикутна напруга, щзо формується на виході інтегратора інтегруванням прямокутних біполярних меандрів, які утворюються 3 вихідних сигналів дільника частоти фазорозчеплювача, синхронізованого з мережею за допомогою пристрою, щуо збільшує частоту в чотири рази (помножувач частоти), який виконано на основі оригінальної прецизійної амлітудно-імпульсної системи фазового автопідстроювання частоти. Як первинні перетворювачі застосовуються компенсаційні малогабаритні низьковольтні трансформатори з використанням вимірювальних підсилювачів з диференційно розщепленими входами, щзо забезпечує підвищення лінійності характеристики в широкому динамічному діапазоні, завдяки чому реалізується адитивно-мультиплікативна корекція похибок всього вимірювального тракту по двом точкам. У статті наведено результати комп'ютерного моделювання основних функціональних компонентів вимірювального каналу, які підтверджують його прецизійність та високі метрологічні характеристики. Бібл. 10, рис. 2.

Ключові слова: автоматична корекція похибок, активна потужність, вимірювальний канал, система синхронізації, частотні складові похибок, фазове автоналаштування частоти. 